\title{
PENGELOLAAN KONFLIK AKTIVITAS BISNIS PERSPEKTIF ISLAM PADA MANAJEMEN PASAR INDUK PUSPA AGRO JAWA TIMUR
}

\author{
Citra Rahayu Indraswari \\ Mahasiswa Program Studi S-1 Ekonomi Islam - Fakultas Ekonomi dan Bisnis - Universitas \\ Airlangga \\ Email: citraindraswari@gmail.com \\ Muhammad Nafik HR. \\ Departemen Ekonomi Syariah - Fakultas Ekonomi dan Bisnis - Universitas Airlangga \\ Email: manhard999@yahoo.com
}

\begin{abstract}
Conflict is something that can not be separated in the process of management of the company. Conflict that managed well will be able to make a positive contribution to the business activities and the achievement of corporate goals. This study used a qualitative research methodology with a case study approach. The selection of a qualitative methodology based on the problem formulation used in this study

The results of this study indicate that the conflicts that happened in management Central Market Puspa Agro caused by internal and external factor. Internal factor is derived from obscurity powers, functions and roles, monitoring and evaluation weakness, slowness of responds to the problems, the competence of individual differences, the target and task interdependence. External factors consist of the presence of government policies and industry demands. The effect of conflicts are functional and dysfunctional. Conflicts levels are low, optimal and high .

Conflict management is applied by stimulation, reduction of conflict and conflict resolution methods. Conflict stimulation methods include the application of the system of reward and punishment and the different treatment of habit . Conflict reduction methods include the provision of a forum for dialogue, joint activities and creating new challenges. Conflict resolution methods include the expansion of resources, compromise, change the variable structure of the company, avoiding and otorative command.

Keywords : Conflict, Resource of Conflict, Conflict Management Method, Stimulation Of Conflict, Conflict Reduction, Conflict Resolution
\end{abstract}

\section{PENDAHULUAN}

\section{A. Latar Belakang}

Konflik telah menjadi sebuh subjek studi sejak peradaban kuno dan selalu menjadi bahan diskusi apakah konflik itu ada sebagai sebuah proses yang konstruktif atau proses yang destruktif. Konflik tercipta seiring penciptaan manusia didunia. Penciptaan Nabi Adam as dan hawa didunia juga tidak terlepas dari adanya konflik. Bahkan pembunuhan pertama manusia didunia oleh Habil dan Qabil juga dikarenakan konflik kepentingan. Kisah konflik manusia yang pertama kali ini diabadikan oleh Al Quran dalam Surat Al Maidah ayat 27:

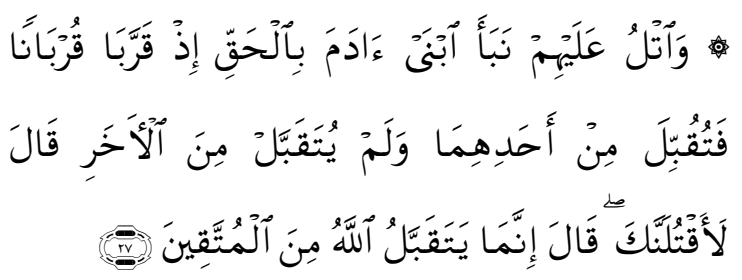

"Wautlu 'alayhim naba-a ibnay âdama
bialhaqqi idz qarrabâ qurbânan
fatuqubbila min ahadihimâ walam
yutaqabbal mina al-âkhari qâla la- 
aqtulannaka qâla innamâ yataqabbalu allâhu mina almuttaqîna"

27. Ceritakanlah kepada mereka kisah kedua putera Adam (Habil dan Qabil) menurut yang sebenarnya, ketika keduanya mempersembahkan korban, Maka diterima dari salah seorang dari mereka berdua (Habil) dan tidak diterima dari yang lain (Qabil). ia berkata (Qabil): "Aku pasti membunuhmu!". berkata Habil: "Sesungguhnya Allah hanya menerima (korban) dari orang-orang yang bertakwa". (QS: Al Maidah:27)

Pada saat ini banyak kita jumpai konflik yang terjadi di dalam dunia industri dan organisasi. Konflik sendiri diartikan sebagai reaksi psikologis danperilaku (behavioral) terhadap suatu persepsi bahwa orang lain menghalangi Anda dalam mencapai suatu tujuan, mengambil hak untuk berperilaku dalam suatu cara tertentu, atau merusak pengharapan-pengharapan dari suatu hubungan (dalam Aamodt, 2007). Pendapat lain mengatakan bahwa konflik adalah suatu proses yang dimulai saat satu pihak memandang bahwa pihak lainnya frustrasi, atau akan mengalami frustrasi oleh kepentingan pihak mereka (dalam Dunnette, 1988).

Organisasi adalah sarana dalam pencapaian tujuan, yang merupakan wadah kegiatan dari orang-orang yang bekerja sama dalam usahanya mencapai tujuan, baik tujuan jangka pendek maupun jangka panjang. Organisasi atau perusahaan harus mampu mengelolah manajemennya untuk memenangkan persaingan pada era yang serba kompetitif supaya dapat bertahan untuk tumbuh dan berkembang sesuai dengan tujuan perusahaan. Setiap perusahaan, baik yang bergerak dibidang produksi, jasa maupun industri, pada umumnya memiliki tujuan untuk memperoleh keuntungan. Supaya dapat mencapai tujuan itu, perusahaan memerlukan sistem manajemen efektif yang akan menunjang jalannya operasi perusahaan secara terusmenerus dan tingkat efektivitas kerja karyawan juga perlu diperhatikan untuk mencapai dan memelihara keberlangsungan sehingga tujuan dalam jangka panjang (sustainability) dapat tercapai. Salah satu upaya yang dapat dilakukan untuk mencapai tujuan oganisasi yang optimal adalah dengan implementasi pengelolaan konflik yang tepat bagi setiap konflik yang muncul dalam perusahaan.

Pengelolaan konflik merupakan serangkaian aksi dan reaksi antara pelaku maupun pihak luar dalam suatu konflik. Pengelolaan konflik termasuk pada suatu pendekatan yang berorientasi pada proses yang mengarahkan pada bentuk komunikasi (termasuk tingkah laku) dari pelaku maupun pihak luar dan bagaimana mereka mempengaruhi kepentingan (interests) dan interpretasi.Pengelolaan konflik bertujuan mengatur tingkat konflik yang sehat dan mencegah konflik tumbuh secara tidak terkendali (Jones,2001:420-422). Stoner dan Freeman (1989:391) mengemukakan bahwa konflik yang berlebihan maupun terlalu sedikit dapat menghambat kreativitas organisasi (kontraproduktif), namun ketika konflik dapat dikelola 
secara baik permasalahan dapat diselesaikan secara efektif dan memungkinkan menjadi lebih inovatif. Daft (2011) menyatakan bahwa konflik yang halus sebenarnya dapat menjadi sebuah keuntungan dalam tim. Tingkat konflik yang sehat akan membantu mencegah terjadinya groupthink, dimana orang-orang terlalu berkomitmen terhadap kepaduan tim sehingga menjadi malas mengungkapan opin-opini yang berlawanan.

Tabel 1.

Hubungan Tingkat Konflik dan Kinerja Organisasi

\begin{tabular}{|c|c|c|c|}
\hline $\begin{array}{l}\text { Tingkat } \\
\text { Konflik }\end{array}$ & $\begin{array}{l}\text { Tipe } \\
\text { Konflik }\end{array}$ & $\begin{array}{l}\text { Pengaruh } \\
\text { Organisasi }\end{array}$ & $\begin{array}{l}\text { Tingka } \\
\dagger \\
\text { Kinerja }\end{array}$ \\
\hline $\begin{array}{l}\text { Renda } \\
\text { h atau } \\
\text { tidak } \\
\text { ada }\end{array}$ & $\begin{array}{l}\text { Disfungsi } \\
\text { onal }\end{array}$ & $\begin{array}{l}\text { 1. Apatis } \\
2 . \\
\text { Membosanka } \\
n \\
\text { 3. Tidak ada } \\
\text { respon untuk } \\
\text { berubah } \\
4 . \\
\text { Kekurangan } \\
\text { ide dan } \\
\text { inovasi }\end{array}$ & $\begin{array}{l}\text { Renda } \\
\mathrm{h}\end{array}$ \\
\hline $\begin{array}{l}\text { Optima } \\
\text { I }\end{array}$ & $\begin{array}{l}\text { Fungsion } \\
\text { al }\end{array}$ & $\begin{array}{l}\text { 1. } \\
\text { Bersemangat } \\
\text { 2. Kritik diri } \\
\text { 3. Inovatif }\end{array}$ & Tingi \\
\hline Tinggi & $\begin{array}{l}\text { Disfungsi } \\
\text { onal }\end{array}$ & $\begin{array}{l}\text { 1. Memecah } \\
\text { belah } \\
\text { 2. Tidak } \\
\text { mampu } \\
\text { bekerjasama } \\
\text { 3. Tingkat } \\
\text { stress tinggi }\end{array}$ & $\begin{array}{l}\text { Renda } \\
\mathrm{h}\end{array}$ \\
\hline
\end{tabular}

Model pengelolaan konflik dalam suatu organisasi akan sangat mempengaruhi kinerja organisasi tersebut. Robbins (2006:151) mengemukakan bahwa tingkatan konflik tertentu akan berdampak pada keluaran atau hasil dari kinerja organisasi. Kemampuan mempersepsikan dan mengelola konflik mampu memberikan sebuah proses pembelajaran yang membantu sebuah organisasi menjadi dewasa melalui perubahan perilaku secara positif anggota-anggota organisasi didalamnya.

Upaya mengelola konflik dan menyadari bahwa keberadaan konflik adalah sebuah hal yang wajar dalam setiap aktivitas manusia juga dijelaskan secara tegas dalam Al Quran. Dalam Islam, konflik bukanlah sebagai tujuan namun lebih sebagai sarana untuk memadukan antara berbagai hal yang saling bertentangan untuk membebaskan kehidupan manusia dari kepentingan individual dan dari kejelekan-kejelekan, sehingga tidak membiarkan perbedaanperbedaan itu menjadi penyebab adanya permusuhan. Karena sesungguhnya manusia berasal dari asal yang sama. Seperti dijelaskan pada surat An Nisaa' ayat 1:

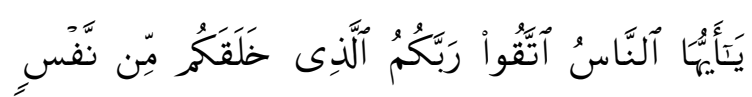

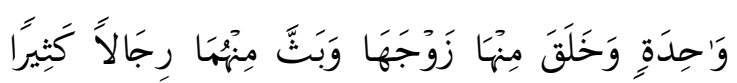

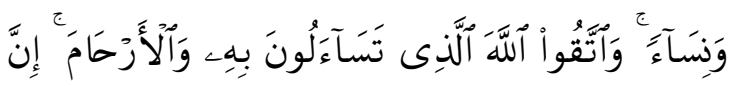

$$
\text { أَلَّهَ كَانَ عَلَيَكُمُمْ رَقِيبًا }
$$

"Yâ ayyuhâ alnnâsu ittaqû rabbakumu alladzî khalaqakum min nafsin wâhidatin wakhalaqa minhâ zawjahâ wabatstsa minhumâ rijâlan katsîran wanisâ-an waittaqû allâha alladzî tasâ-alûna bihi wâl-arhâma inna allâha kâna 'alaykum raqiiban"

1. Hai sekalian manusia, bertakwalah kepada Tuhan-mu yang telah menciptakan kamu dari seorang diri, dan dari padanya Allah menciptakan isterinya; 
dan dari pada keduanya Allah memperkembang biakkan laki-laki dan perempuan yang banyak. dan bertakwalah kepada Allah yang dengan (mempergunakan) nama-Nya kamu saling meminta satu sama lain, dan (peliharalah) hubungan silaturrahim. Sesungguhnya Allah selalu menjaga dan mengawasi kamu. (QS: An Nisaa': 1)

Dari ayat diatas dapat ditarik kesimpulan bahwa sebenarnya manusia berasal dari asal yang sama. Islam mengajarkan pentingnya untuk toleransi menghargai adanya perbedaanperbedaan yang dimiliki manusia baik dari fisik, pemikiran budaya dan lain-lain. Konflik memang sering muncul dalam kehidupan manusia. Namun, jangan sampai terlarut dalam konflik yang akhirnya menjadi konflik berkepanjangan yang tidak ada solusinya yang justru akan merusak hubungan antar manusia dan akan merugikan manusia itu sendiri. Oleh sebab itu diperlukan sebuah kemampuan dalam mengelola konflik agar tidak sampai memicu munculnya perselisihan dan mengakibatkan perseteruan dan permusuhan yang dapat merugikan.

Perkembangan pemkirian tentang pengelolaan konflik telah menggeser paradigma mengenai keberadaan konflik dan akibatnya terhadap kinerja dan keberlangsungan organisasi. Susilo Martoyo (1998:179) mengemukakan pandangan tentang konflik secara tradisional dan modern. Pandangan tradisional memaknai konflik merupakan hal yang tidak dînginkan dan berbahaya bagi suatu organisasi, mereka yang berpandangan tradisional ini menganggap jikalau terjadi konflik pasti terjadi sesuatu yang tidak beres dalam organisasi. Ketidakberesan dalam organisasi ini harus segera diperbaiki, sehingga fungsi-fungsi dalam organisasi dapat berjalan dengan terintegrasi kembali secara baik. Sedangkan pandangan modern / kontemporer tentang konflik mengemukakan bahwa konflik dapat dijadikan sebuah stimulus dinamika organisasi oleh sebab itu diperlukan sebuah pengelolaan konflik yang tepat sehingga konflik yang ada mampu bersifat fungsional.

Robbin (1996: 431) mengatakan konflik dalam organisasi disebut sebagai The Conflict Paradoks, yaitu pandangan bahwa di sisi konflik dianggap dapat meningkatkan kinerja kelompok, tetapi di sisi lain kebanyakan kelompok dan organisasi berusaha untuk meminimalisasikan konflik. Pandangan ini dibagi menjadi tiga bagian. Pandangan tradisional menyatakan bahwa konflik itu hal yang buruk, sesuatu yang negatif, merugikan, dan harus dihindari. Konflik disinonimkan dengan istilah violence, destruction, dan irrationality. Konflik ini merupakan suatu hasil disfungsional akibat komunikasi yang buruk, kurang kepercayaan, keterbukaan di antara orang - orang, dan kegagalaan manajer untuk tanggap terhadap kebutuhan dan aspirasi karyawan. Pandangan hubungan manusia (The Human Relation View) menyatakan bahwa konflik dianggap sebagai suatu peristiwa yang wajar terjadi di dalam kelompok atau organisasi. Konflik 
dianggap sebagai sesuatu yang tidak dapat dihindari karena di dalam kelompok atau organisasi pasti terjadi perbedaan pandangan atau pendapat antar anggota. Oleh karena itu, konflik harus dijadikan sebagai suatu hal yang bermanfaat guna mendorong peningkatan kinerja organisasi. Dengan kata lain, konflik harus dijadikan sebagai motivasi untuk melakukan inovasi atau perubahan di dalam tubuh kelompok atau organisasi. Pandangan interaksionis (The Interactionist View) cenderung mendorong suatu kelompok atau organisasi terjadinya konflik. Hal ini disebabkan suatu organisasi yang kooperatif, tenang, damai, dan serasi cenderung menjadi statis, apatis, tidak aspiratif, dan tidak inovatif. Oleh karena itu, menurut pandangan ini, konflik perlu dipertahankan pada tingkat minimum secara berkelanjutan sehingga tiap anggota di dalam kelompok tersebut tetap semangat, kritis - diri, dan kreatif.

Pasar sebagai sebuah organisasi berfungsi sebagai salah satu sendi perekonomian dimana aktivitas jual-beli berlangsung setiap harinya. Keberadaan pasar yang vital dalam kehidupan manusia menjadikan potensi konflik yang muncul semakin besar. Pupsa Agro, salah satu pasar induk yang menjadi sentra perdagangan industri agro di Jawa Timur mengalami permasalahan yang serupa. Konflik menjadi bagian dari setiap kegiatan pengelolaan yang di lakukan.

Pasar Induk Modern Puspa Agro dikembangkan dengan lahan seluas 50 hektar, diproyeksikan sebagai Pasar induk terbesar dan terlengkap di Indonesia, Puspa Agro dikelola dengan konsep mengintegrasikan berbagai produk agro dalam satu kawasan yang tertata rapi. Terdapat empat hal yang mendasarinya. Pertama, melimpahnya produksi pangan dan hortikultura Jatim. Indikasinya, Jatim mampu memasok produk pangan dan hortikultura sekitar 35\% terhadap stok nasional. Kedua, masih terbatasnya akses dan kurangnya pasar yang representatif untuk memasarkan produksi petani di Jatim. Ketiga, belum tersedianya tempat atau pasar khusus untuk memasarkan produk pangan dan hortilultura (agrobis) dalam skala besar, keempat, masih terbukanya peluang untuk meningkatkan penjualan hasil pertanian,baik untuk skala regional, nasional,maupun internasional (ekspor).

Pasar Induk Modern Puspa Agro memiliki prospek untuk dikembangkan sebagai sentra perdagangan agro (agobis), tidak saja di skala lokal dan regional, tetapi berpotensi kuat menjadi barometer perdagangan di kawasan Indonesia Timur. Bahkan, Puspa Agro akan menjadi sarana efektif untuk menembus pasar internasional (ekspor) atau global market. Diperkirakan, potensi transaksi di Puspa Agro mencapai Rp 10 triliun hingga Rp 12 trilun per tahun (puspaagro.com). Los seluas $60 \times 160$ meter terdiri 192 lapak yang setiap lapak ukuran $4 \times 6$ meter saat ini penuh dengan pedagang palawija dari berbagai daerah Jawa Timur. Jumlah pedagang per losnya sekitar 300 orang. 


\begin{abstract}
Dtinjau dari segi kelayakan bisnisnya Puspa Agro memang sebuah proyek yang sangat potensial memberikan kontribusi ekonomis terhadap perkembangan perekonomian di Jawa Timur. Namun jika dilihat realitanya pasar yang diresmikan lima tahun silam ini belum juga mencapai target pembangunannya. Bahkan kondisi dilapangan sangat jauh berbeda dengan pemberitaan yang dirilis secara resmi oleh pengelola.

Belum optimalnya fungsi organisasi dijalankan mengindikasikan adanya suatu konflik. Sesuai definisinya konflik dapat diartikan sebagai sebuah ketidaksesuain karena adaya perbedaan yang mempengaruhi proses pencapaian tujuan organisasi. Berdasarkan fenomena yang terjadi tersebut, maka penulis tertarik untuk melakukan penelitian menyusun sebuah karya ilmiah dengan judul " Pengelolaan Konflik Aktivitas Bisnis Perspektif Islam Pada Manajemen Pasar Induk Puspa Agro Jawa Timur"
\end{abstract}

\section{LANDASAN TEORI \\ PENGEMBANGAN PROPOSISI}

\section{A. Pengertian Konflik}

Organisasi terdiri dari berbagai macam komponen yang tidak jarang komponen-komponen tersebut bersinggungan dan menjadikan suatu konflik didalamnya. Konflik adalah sebuah proses yang dimulai ketika satu pihak memiliki persepsi bahwa pihak lain telah memengaruhi secara negatif, atau akan memengaruhi secara negatif, sesuatu yang menjadi kepedulian atau kepentingan pihak pertama. Definisi ini mencakup beragam konflik yang orang alami dalam organisasi, ketidakselarasan tujuan, perbedaan interpretasi fakta, ketidaksepahaman yang disebabkan oleh ekspetasi perilaku, dan sebagainya (Robbins, 2006:505).

Panji Anoraga dan Sri Suryati (1997:131) mendefinisikan " Konflik merupakan semua bentuk benturan/tabrakan, ketidaksesuaian, pertentangan, perkelahian, oposisi dan interaksi yang antagonis bertentangan'. Wahyudi (2006:17) mengutip pernyataan Wood, Walace, Zeffane, Schermerhorn, Hunt, dan Osborn yang mendefinisikan konf lik (dalam ruang lingkup organisasi) adalah suatu situasi dimana dua atau banyak orang saling tidak setuju terhadap suatu permasalahan yang menyangkut kepentingan organisasi dan atau dengan timbulnya perasaan permusuhan satu dengan yang lainnya. Sedangkan Stoner mendefinisikan konflik organisasi adalah mencakup ketidaksepakatan soal alokasi sumberdaya yang langka atau peselisihan soal tujuan, status, nilai, persepsi, atau kepribadian.

Veitzhal Rivai (2005:507) menjelaskan pengertian "Konflik kerja adalah ketidaksesuaian antara dua atau lebih anggota-anggota atau kelompok (dalam suatu organisasi/perusahaan) yang harus membagi sumber daya yang terbatas atau kegiatan-kegiatan kerja dan atau karena kenyataan bahwa mereka mempunyai perbedaan status, tujuan nilai atau persepsi". Albanse dalam Nimran 
(1997:60) menyatakan konflik sebagai kondisi yang dipersepsikan ada diantara pihak-pihak (individu, kelompok dan lainlain), dimana salah satu pihak atau lebih merasakan adanya ketidaksesuaian tujuan dan peluang untuk mencampuri usaha pencapaian tujuan pihak lain.

\section{B. Pandangan Tentang Konflik}

Islam mencitrakan perdamaian sesuai dengan makna kata Islam, yaitu "salam", hal tersebut tidak berarti Islam tidak memberikan pandangan terhadap konflik yang diametral terhadap perdamaian. Islam memungkinkan memberikan pemaknaan konflik dalam bentuk dan formula yang ramah dan damai, sehingga konflik tidak semata dimaknai sebagai suatu hal destruktif dan kontra-produktif, namun bisa menjadi sebuah stimulus untuk gejala yang konstruktif bahkan produktif (Surwandono\&Ahmadi, 2011:9).

\begin{tabular}{|c|c|c|c|}
\hline Hafidh & uddin & dan & Tanjung \\
\hline menyatakan & bahwa & konflik & dalam \\
\hline
\end{tabular}
pendapat yang terus menerus serta tidak terakomodasi dengan baik akan menimbulkan konflik dan pertentangan yang membahayakan. Konflik semacam ini disebut tanazu, sebagaimana dinyatakan dalam Al Qur'an surat AlAnfaal ayat 46 :

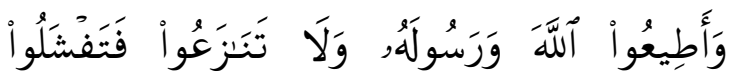

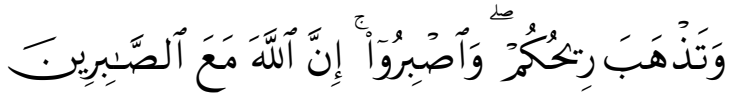

"Waathî̀ allâha warasûlahu walâ tanâza'û fatafsyalû watadzhaba rîhukum waishbirû inna allâha ma'a alshshaabirîna"

46. Dan taatlah kepada Allah dan RasulNya dan janganlah kamu berbantahbantahan, yang menyebabkan kamu menjadi gentar dan hilang kekuatanmu dan bersabarlah. Sesungguhnya Allah beserta orang-orang yang sabar. (QS: Al Anfaal:46)

\section{Teknik-Teknik Pengelolaan Konflik}

Untuk meredakan konflik yang ada, diperlukan untuk mempelajari teknik-teknik pengelolaan konflik. Pengelolaan konflik adalah pemanfaatan teknik-teknik resolusi dan dorongan (stimulasi) untuk mencapai tingkat konflik yang dînginkan (Robbins, 2006:513). 
Tabel 2.

Teknik-Teknik Pengelolaan Konflik

\begin{tabular}{|c|c|}
\hline \multicolumn{2}{|c|}{$\begin{array}{l}\text { Teknik-teknik penyelesaian } \\
\text { Konflik }\end{array}$} \\
\hline $\begin{array}{l}\text { Pe } \\
\text { me } \\
\text { cah } \\
\text { an } \\
\text { mas } \\
\text { ala } \\
\text { h }\end{array}$ & $\begin{array}{l}\text { Pertemuan } \\
\text { tatap muka } \\
\text { pihak-pihak } \\
\text { yang } \\
\text { berkonflik } \\
\text { untuk } \\
\text { mengidentifika } \\
\text { si masalah } \\
\text { dan } \\
\text { menyelesaika } \\
\text { nnya melalui } \\
\text { diskusi terbuka }\end{array}$ \\
\hline $\begin{array}{l}\text { Tuju } \\
\text { an } \\
\text { sup } \\
\text { eror } \\
\text { din } \\
\text { at }\end{array}$ & $\begin{array}{l}\text { Menetapkan } \\
\text { tujuan } \\
\text { bersama yang } \\
\text { tidak dapat } \\
\text { dicapai tanpa } \\
\text { kerja sama } \\
\text { dari setiap } \\
\text { pihak yang } \\
\text { berkonflik }\end{array}$ \\
\hline $\begin{array}{l}\text { Eks } \\
\text { pan } \\
\text { si } \\
\text { sum } \\
\text { ber } \\
\text { day } \\
\text { a }\end{array}$ & $\begin{array}{l}\text { Ketika sebuah } \\
\text { konflik timbul } \\
\text { karena } \\
\text { kelangkân } \\
\text { sumber daya } \\
\text { (Uang,promosi } \\
\text {,kesempatan,r } \\
\text { uang kantor) } \\
\text { ekspansi } \\
\text { sumber daya } \\
\text { dapat } \\
\text { menciptakan } \\
\text { solusi yang } \\
\text { saling } \\
\text { menguntungk } \\
\text { an }\end{array}$ \\
\hline $\begin{array}{l}\text { Pen } \\
\text { ghi } \\
\text { nda } \\
\text { ran }\end{array}$ & $\begin{array}{l}\text { Penarikan diri } \\
\text { dari, atau } \\
\text { penyembunyi } \\
\text { an, konflik }\end{array}$ \\
\hline $\begin{array}{l}\text { Me } \\
\text { mp } \\
\text { erh } \\
\text { alus }\end{array}$ & $\begin{array}{l}\text { Meminimalkan } \\
\text { perbedaan } \\
\text { sembari } \\
\text { menekankan } \\
\text { kepentingan } \\
\text { bersama di } \\
\text { antara pihak- } \\
\text { pihak yang } \\
\text { berkonflik }\end{array}$ \\
\hline
\end{tabular}

\begin{tabular}{|c|c|}
\hline $\begin{array}{l}\text { Berk } \\
\text { om } \\
\text { pro } \\
\text { mi }\end{array}$ & $\begin{array}{l}\text { Masih masing- } \\
\text { masing pihak } \\
\text { yang } \\
\text { berkonflik } \\
\text { menyerahkan } \\
\text { sesuatu yang } \\
\text { bernilai }\end{array}$ \\
\hline $\begin{array}{l}\text { Peri } \\
\text { nta } \\
\text { h } \\
\text { otor } \\
\text { atif }\end{array}$ & $\begin{array}{l}\text { Manajemen } \\
\text { menggunakan } \\
\text { wewenang } \\
\text { formalnya } \\
\text { untuk } \\
\text { menyelesaika } \\
\text { n konflik dan } \\
\text { kemudian } \\
\text { menyampaika } \\
\text { n } \\
\text { keinginannya } \\
\text { kepada pihak- } \\
\text { pihak yang } \\
\text { terlibat }\end{array}$ \\
\hline $\begin{array}{l}\text { Me } \\
\text { ngu } \\
\text { bah } \\
\text { vari } \\
\text { abe } \\
\text { I } \\
\text { ma } \\
\text { nusi } \\
\text { a }\end{array}$ & $\begin{array}{l}\text { Menggunakan } \\
\text { teknik-teknik } \\
\text { perbuahan } \\
\text { perilaku } \\
\text { seperti } \\
\text { pelatihan } \\
\text { hubungan } \\
\text { insani untuk } \\
\text { mengubah } \\
\text { sikap dan } \\
\text { perilaku yang } \\
\text { menyebabkan } \\
\text { konflik }\end{array}$ \\
\hline $\begin{array}{l}\text { Me } \\
\text { ngu } \\
\text { bah } \\
\text { vari } \\
\text { abe } \\
\text { I } \\
\text { stru } \\
\text { ktur } \\
\text { al }\end{array}$ & $\begin{array}{l}\text { Mengubah } \\
\text { struktur } \\
\text { organisasi } \\
\text { formal dan } \\
\text { pola-pola } \\
\text { interaksî dari } \\
\text { pihak-pihak } \\
\text { yang } \\
\text { berkonflik } \\
\text { melalui } \\
\text { rancang ulang } \\
\text { pekerjaan, } \\
\text { pemindahanm } \\
\text { penciptaan } \\
\text { posisi } \\
\text { koordinasi, } \\
\text { dan } \\
\text { sebagainya. }\end{array}$ \\
\hline \multicolumn{2}{|c|}{$\begin{array}{l}\text { Teknik-Teknik Stimulasi } \\
\text { Konflik }\end{array}$} \\
\hline $\begin{array}{l}\text { Ko } \\
\mathrm{mu}\end{array}$ & $\begin{array}{l}\text { Menggunakan } \\
\text { pesan-pesan }\end{array}$ \\
\hline
\end{tabular}




\begin{tabular}{|c|l|}
\hline nika & ambigu atau \\
si & yang sifatnya \\
& mengancam \\
& untuk \\
& menaikan \\
& tingkat konflik \\
\hline Me & Menambahka \\
mas & nkaryawan ke \\
ukk & suatu \\
ora & kelompok \\
ng & dengan latar \\
luar & belakang, \\
& nilai-nilai, \\
& sikap, atau \\
gaya \\
mita
\end{tabular}

Sumber: Robbins, Stephen P. 2006.

Managing Organizational Conflict:A

=Nontraditional Approach. New York:

Prentice Hall.

III. METODE PENELITIAN

A. Pendekatan Penelitian
Pendekatan yang digunakan dalam penelitian ini adalah kualitatif dengan strategi pendekatan studi kasus eksplanatoris. Menurut Yin (2009:1) secara umum, studi kasus merupakan strategi yang lebih cocok bila pokok pertanyaan suatu penelitian berkenaan dengan how atau why, bila peneliti hanya memiliki sedikit peluang untuk mengontrol peristiwa-peristiwa yang akan diselidiki, dan bilamana fokus penelitiannya terletak pada fenomena kontemporer (masa kini) di dalam konteks kehidupan nyata.

\section{B. Ruang Lingkup Penelitian}

Ruang lingkup penelitian ini terbatas pada bagaimanakah manajemen Pasar Induk Puspa Agro menerapkan pengelolaan konflik dalam menjalankan aktivitas bisnisnya. Aspek konflik yang diamati adalah konflik yang ada pada Badan Pengelola yang mengelola unit Puspa Agro.

\section{Teknik Penentuan Informan}

Dalam penelitian ini informan didapatkan dengan menggunakan Purposive sampling yakni teknik pengambilan sampel sumber data dengan pertimbangan tertentu.

\section{Data dan Sumber Data}

Menurut Afifuddin dan Saebani (2009:119) dalam penelitian kualitatif, pengumpulan data bukan hanya melalui partisipasi, juga melalui literatur, baik sebagai data primer maupun sebagai data sekunder

\section{E. Teknik Pengumpulan Data}

Dalam penelitian kualitatif pengumpulan data dapat dilakukan dengan menggunakan beberapa cara yaitu 
wawancara, observasi, dan studi kepustakaan (Afifuddin dan Saebani, 2009:131). Jumlah informan dalam penelitian ini tergantung dari banyaknya dan keberagaman informasi yang diterima peneliti. Apabila informasi yang didapat tidak berkembang (jenuh) dan dirasa telah mewakili apa yang diharapkan sebelumnya, pencarian informan berhenti saat itu juga.

\section{Unit Analisis}

Penelitian ini menganalisis tentang kondisi konflik dan pengelolaan konflik aktivitas bisnis pada pengelolaan Pasar Induk Puspa Agro yang meliputi teknik stimulasi, pengelolaan tingkat konflik optimal dan resolusi konflik serta strategi penanganan yang dipilih dalam satu unit Badan Pengelola yaitu Badan Pengelola Pasar Puspa Agro pada PT. Jatim Graha Utama.

\section{F. Teknik Analisis}

Yin (2012:133) berpendapat tentang tiga macam bentuk teknik analisis yang sering digunakan antara lain penjodohan pola, pembuatan penjelasan (deskriptif), dan analisis deret waktu. Teknik analisis yang digunakan dalam penelitian ini adalah teknik analisis deskriptif atau dapat disebut pembuatan penjelasan, yaitu dengan menggunakan metode analisis data dan mendeskripsikan hasil observasi wawancara, serta bertujuan untuk mengetahui secara lebih mendalam.

\section{DESKRIPSI HASIL DAN PEMBAHASAN}

\section{A. Pembahasan Hasil Penelitian}

Konflik merupakan hal yang wajar dalam setiap aktivitas yang melibatkan interaksi antar individu maupun kelompok terlebih dalam sebuah perusahaan yang memiliki aktivitas bisnis dan kebergaman kepentingan. Konflik menurut Myers (1993:234) dapat dipahami berdasarkan dua sudut pandang yaitu tradisional dan kontemporer. Dalam pandangan tradisional, konflik dianggap sebagai sesuatu yang buruk yang harus dihindari. Pandangan ini sangat menghindari adanya konflik karena dinilai sebagai faktor penyebab pecahnya suatu kelompok atau organisasi. Bahkan seringkali konflik dikaitkan dengan kemarahan, agresivitas, dan pertentangan baik secara fisik maupun dengan kata-kata kasar yang pada akhirnya justru akan menimbulkan konfik yang lebih besar. Pandangan kontemporer mengenai konflik didasarkan pada anggapan bahwa konflik merupakan sesuatu yang tidak dapat dielakkan sebagai konsekuensi logis interaksi manusia.

Fokus utama adalah bukan bagaimana menghilangkan konflik, tapi bagaimana menanganinya secara tepat sehingga tidak merusak hubungan antarpribadi, kelompok bahkan merusak tujuan perusahaan. Konflik dianggap sebagai suatu hal yang wajar di dalam perusahaan sebagai sebuah organisasi. Konflik bukan dijadikan suatu hal yang destruktif, melainkan harus dijadikan suatu hal konstruktif untuk membangun organisasi tersebut, misalnnya bagaimana cara peningkatan kinerja organisasi.

Islam memiliki pandangan yang sama terhadap konflik. Meskipun Islam 
yang notabene lebih mengutamakan perdamaian, sesuai dengan makna kata Islam sendiri yakni "salam", bukan berarti Islam tidak memberikan makna dan pandangan terhadap konsepsi konflik. Islam memaknai konflik bisa dalam bentuk yang lebih ramah dan damai. Konsep Islam mengenai konflik tidak harus difahami sebagai gejala yang destruktif, dan kontraproduktif, namun bisa menjadi gejala yang konstruktif bahkan produktif. Konflik merupakan bagian dari perilaku manusia yang telah dibawa oleh manusia dari sejak dia dilahirkan. Keberadaan konflik sebagai unsur pembawaan sangat penting dalam kehidupan manusia. Kehidupan tidak dapat berjalan dengan baik tanpa ada konflik. Manusia yang memiliki tuntutan serta keinginan yang beraneka ragam dan manusia akan selalu berusaha untuk memenuhi keinginan tersebut. Namun untuk bisa mendapatkannya, mereka akan berkompetisi untuk mendapatkan keinginan tersebut. Dari sini maka dengan adanya konflik akan mengajarkan manusia untuk dapat berfikir lebih maju untuk mendapatkan keinginannya tersebut sehingga akan bermanfaat bagi kehidupannya. Oleh karena itu, Allah membekali nilai-nilai moral pada setiap makhluk dalam kepentingankepentingannya sendiri. Selagi konflik masih dibutuhkan oleh manusia, maka mereka pun dibekali oleh Allah dengan kemampuan untuk berkonflik, baik dalam fisik, roh maupun akalnya, dan sekaligus kemampuan untuk mencari solusinya.
Seperti yang dijelaskan dalam firman Allah dalam surat Al Baqarah ayat 251 :

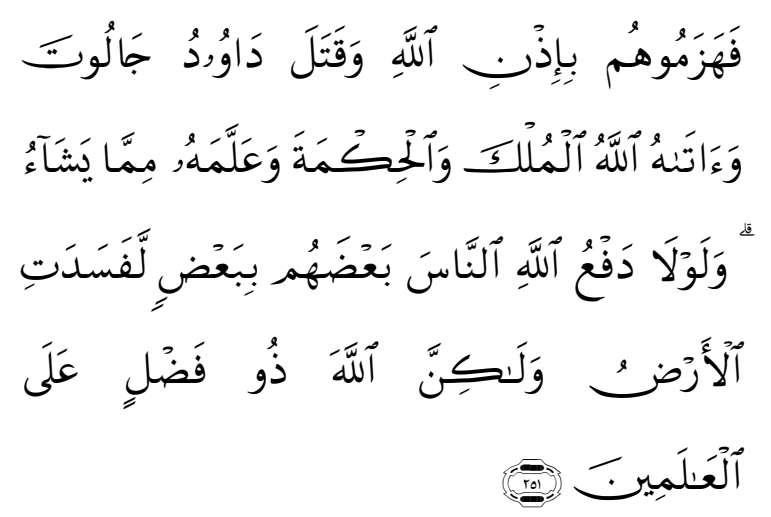

"Fahazamûhum bi-idzni allâhi waqatala dâwûdu jâlûta wâatâhu allâhu almulka wâlhikmata wa'allamahu mimmâ yasyâu walawlâ daf'u allâhi alnnâsa ba'dhahum biba'dhin lafasadati al-ardhu walâkinna allâha dzû fadhlin 'alâ al'âlamîna"

251. Mereka (tentara Thalut) mengalahkan tentara Jalut dengan izin Allah dan (dalam peperangan itu) Daud membunuh Jalut, kemudian Allah memberikan kepadanya (Daud) pemerintahan dan hikmah (sesudah meninggalnya Thalut) dan mengajarkan kepadanya apa yang dikehendaki-Nya. seandainya Allah tidak menolak (keganasan) sebahagian umat manusia dengan sebagian yang lain, pasti rusaklah bumi ini. tetapi Allah mempunyai karunia (yang dicurahkan) atas semesta alam.

Fokus pengelolaan konflik dalam Islam adalah konsep pengelolaan konflik yang ramah dan damai yang diartika sebagai pengelolaan konflik yang menghindari cara-cara kekerasan atau cara-cara yang merusak hubungan serta menimbulkan kedhaliman. Pengelolalan konflik ini sesuai dengan apa yang diungkapkan oleh Tandjung dan Hafidhuddin (2003:192) mengenai teknik pengelolaan konflik dalam Islam yaitu strategi pengelolaan konflik kolaboratif yang memadukan tingkat keasertifan dan tingkat kooperatif secara seimbang. 
Strategi yang diterapkan oleh manajemen dalam mengatasi konflik aktivitas bisnis Pasar Induk puspa Agro adalah strategi pengelolaan konflik secara kolaboratif. Strategi ini mengedepankan pada kepedulian aktif semua pihak yang terfokus, komunikasi dan empati. Pengelola memiliki fokus untuk mampu meningkatkan kualitas dan kuantitas aktivitas bisnis sebagai salah satu unsur penting dalam pengelolaan organisasi.

Antisipasi terhadap potensi konflik disadari oleh pengelola, sehingga konflik yang timbul mampu dikelola secara optimal. Pengelola mampu meminimalisir potensi konflik dengan mengantisipasi adanya asimetris informasi yang menjadi potensi konflik (At Tabayyun). Anjuran bertabayyun dijelaskan Allah swt dalam surat An Nuur ayat 12, dimana tabayyun mencegah konflik karena mendahulukan prasangka baik dengan upaya mencegah asimetris informasi.

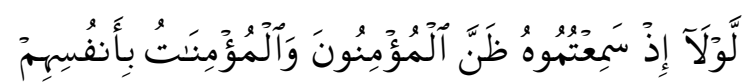

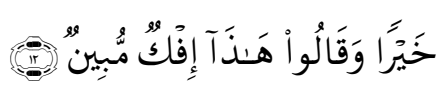

"Lawlâ idz sami'tumûhu zhanna almu/minûna wâlmu'minâtu bi-anfusihim khayran waqâlû hâdzâ ifkun mubînun"

12. "Mengapa di waktu kamu mendengar berita bohon itu orang-orang mukminin dan mukminat tidak bersangka baik terhadap diri mereka sendiri, dan (mengapa tidak) berkata: "Ini adalah suatu berita bohong yang nyata." (QS: An Nuur:12)

Salah satu pengelolaan konflik yang dilakukan oleh manajemen Pasar induk Puspa Agro bertujuan untuk menciptakan iklim berkompetisi yang sehat dan tidak saling merugikan. Islam mendukung upaya kompetisi yang sehat ini dalam balutan konsep kompetisi atau bersaing dalam kebaikan, seperti yang dijelaskan oleh firman Allah swt dalam surat Al Baqarah ayat 148:

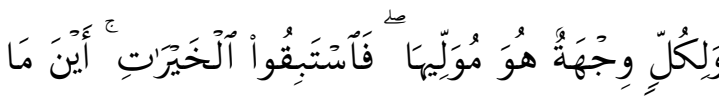

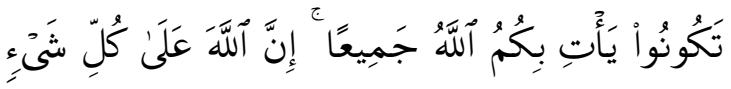
قَدِير "

"Walikullin wijhatun huwa muwallihhâ faistabiqû alkhayrâti aynamâ takûnû ya/ti bikumu allâhu jamîan inna allâha 'alâ kulli syay-in qadîrun"

148. "Dan bagi tiap-tiap umat ada kiblatnya (sendiri) yang ia menghadap kepadanya. Maka berlomba-lombalah (dalam membuat) kebaikan. di mana saja kamu berada pasti Allah akan mengumpulkan kamu sekalian (pada hari kiamat). Sesungguhnya Allah Maha Kuasa atas segala sesuatu." (QS: Al Baqarah:148)

Penerapan award and punishment telah lama disinggung didalam Al Quran bahwasanya setiap manusia berhak mendapatkan imbalan atas apa yang telah ia kerjakan secara setimpal. Perihal ini tertuang dalam surat An Najm ayat 3941 serta surat At Taubah ayat 105 sebagai berikut:

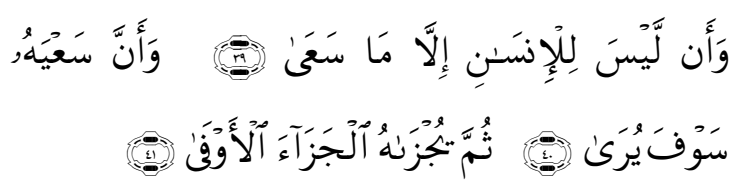

"Wa-an laysa lil-insâni illâ mâ sa'â. Waanna sa'yahu sawfa yurâ. Tsumma yujzâhu aljazô-a al-awfâ"

39. dan bahwasanya seorang manusia tiada memperoleh selain apa yang telah diusahakannya,

40. dan bahwasanya usaha itu kelak akan diperlihat (kepadanya). 
41. kemudian akan diberi Balasan kepadanya dengan Balasan yang paling sempurna. (QS: An Najm:39-41)

Rasulullah saw dalam sebuah hadits yang diriwaytakan oleh Ibnu Majah juga menegaskan keutamana dalam memberikan kompetensi sebagai balas jasa atas kinerja. Berikut adalah hadits Nabi mengenai pentingnya pengimbalan atau kompensasi:

عن ابن عمر أنّ النّبّ صل اله عليه وسلم قال : الأجير أجره قبل أن

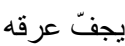

"Dari Ibnu 'Umar bahwa Rasulullah bersabda: berikanlah upah pekerja sebelum keringatnya kering.(HR Ibnu Majah)."

Salah satu gaya penanganan yang diterapkan pada konflik ini adalah dengan strategi berkompromi. Kondisi konflik yang tinggi dan disfungsional disadari oleh manajemen sebagai suatu kondisi yang mengancam keberlangsungan perusahaan. Sehingga upaya-upaya resolusi konflik diterapkan dan tercermin dari upaya-upaya pengelolaan konflik berupa negosisasi (kompromi), megubah variabel struktur organisasi serta ekspansi sumber daya. Upaya negosiasi dilaksanakan dengan memberikan penjelasan mengenai kendala-kendala yang dihadapi. Metode penyelesaian ini dikenal dalam Islam dengan nama Ishlah. Metode Ishlah disebutkan dalam Al Quran sebagai salah satu upaya mengelola konflik yang memberikan efek disfungsional dalam organisasi. Tertuang dalam surat Al Imran ayat 159:

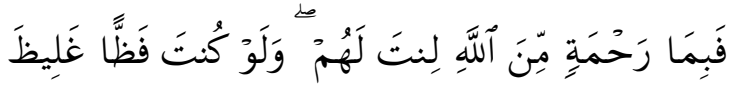

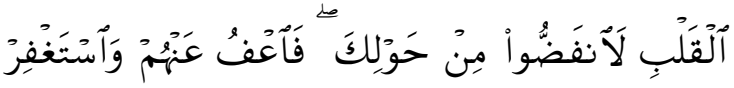

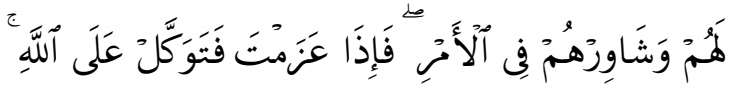

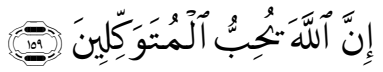

"Fabimâ rahmatin mina allâhi linta lahum walaw kunta fazhzhan ghalizzha alqalbi lainfadhdhû min hawlika fau'fu 'anhum waistaghfir lahum wasyâwirhum fî al-amri fa-idzâ 'azamta fatawakkal 'alâ allâhi inna allâha yuhibbu almutawakkilîna"

159. "Maka disebabkan rahmat dari Allah-lah kamu Berlaku lemah lembut terhadap mereka. Sekiranya kamu bersikap keras lagi berhati kasar, tentulah mereka menjauhkan diri dari sekelilingmu. karena itu ma'afkanlah mereka, mohonkanlah ampun bagi mereka, dan bermusyawaratlah dengan mereka dalam urusan itu, kemudian apabila kamu telah membulatkan tekad, Maka bertawakkallah kepada Allah. Sesungguhnya Allah menyukai orangorang yang bertawakkal kepada-Nya." (QS: Al Imran:159)

Upaya memberikan keterangan atau informasi mengenai kebenaran atas situasi konflik yang terjadi serta upaya penyelesaian konflik juga dilaksanakan dengan menggunakan metode ekspansi sumber daya dilakukan sesuai dengan yang dianjurkan Allah swt dalam surat Al Baqarah ayat 160 :

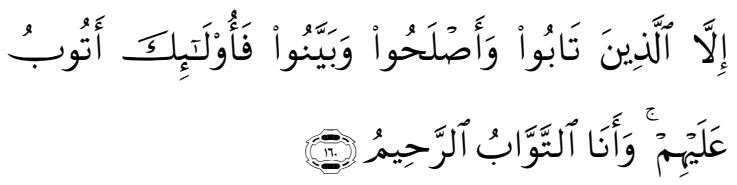

"Illâ alladzîna tâbû wa-ashlahû wabayyanû faulâ-ika atûbu 'alayhim waanâ alttawwâbu alrrahîmu" 160. "Kecuali mereka yang telah taubat dan Mengadakan perbaikandan 
menerangkan (kebenaran), Maka terhadap mereka Itulah aku menerima taubatnya dan Akulah yang Maha menerima taubat lagi Maha Penyayang. (QS: Al Baqarah:160)

Upaya berkompromis tidak jarang memerlukan mediator untuk memfasilitasi pihak-pihak yang berkonflik. Penggunaan mediator atau orang ketiga sebagai salah satu cara penyelesaian konflik juga dianjurkan dalam Al Quran yang dikenal dengan istilah Al-Hakam yang terdapat dalam surat An Nisaa' ayat 35:

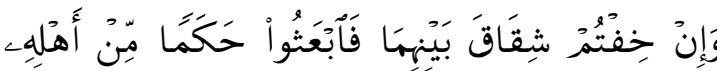

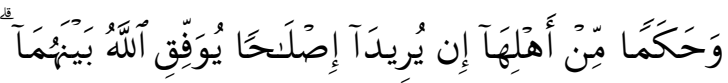

$$
\text { إِنَّ اللَّهَ كَانَ عَلِيمًا خَبِيرًا }
$$

"Wa-in khiftum syiqâqa baynihimâ faib'atsû hakaman min ahlihi wahakaman min ahlihâ in yurîdâ ishlâhan yuwaffiqi allâhu baynahumâ inna allâha kâna 'alîman khabîrân"

35. dan jika kamu khawatirkan ada persengketaan antara keduanya, Maka kirimlah seorang hakamdari keluarga lakilaki dan seorang hakam dari keluarga perempuan. jika kedua orang hakam itu bermaksud Mengadakan perbaikan, niscaya Allah memberi taufik kepada suami-isteri itu. Sesungguhnya Allah Maha mengetahui lagi Maha Mengenal. (QS: An Nisaa':35)

Matrix Startegi Pengelolaan Konflik menjelaskan posisi tipe metode pengelolaan yang digunakan manajemen dalam menyelesaian konflik aktivitas bisnis pada Pasar Induk Puspa Agro yang dikenal dengan matrix $2 \times 2$ (Avruch,1991). Pada gambar 4.6 terlihat Avruch mengkombinasikan kedua peubah yaitu keasertifan dan kekooperatifan sebagai metode yang paling memungkinkan digunakan dalam menyelesaikan konflik.

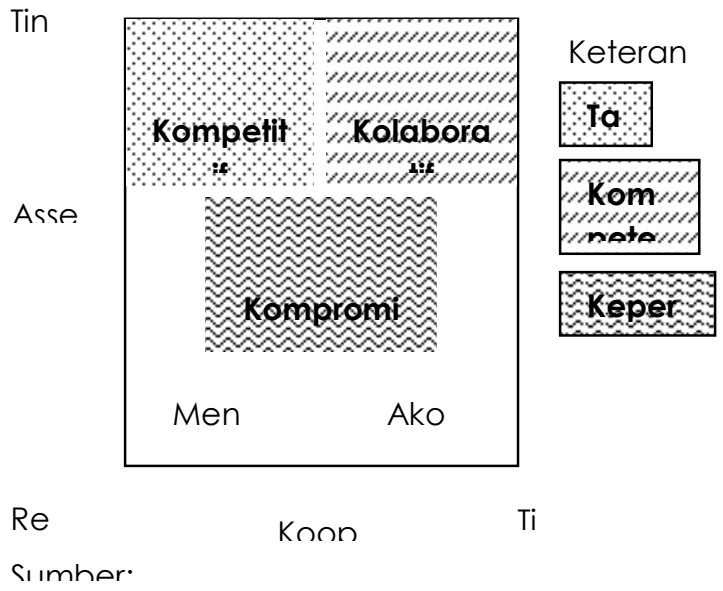

\section{Gambar 1. Matrix Strateqi}

Pengelolaan konflik dengan kecenderungan kooperatif dengan tujuan yang baik dan kekeluargaan sesuai dengan perspektif Islam dalam mengelola konflik, terutama konflik antar sesama muslim (Al Quran ayat 159), sedangkan arah asertif lebih diutamakan digunakan untuk penanganan konflik dengan nonmuslim dan hanya dianjurkan untuk permasalahan ideologis (Al Quran surat An Nahl 125):

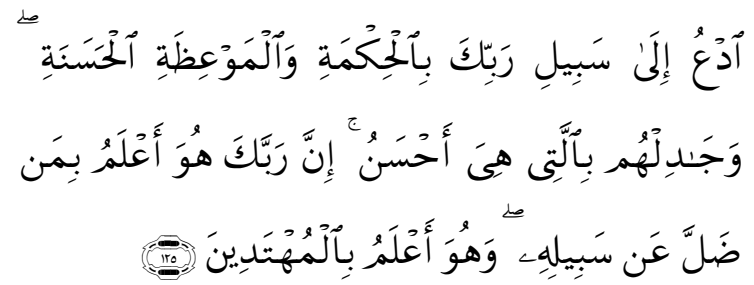

"Ud'u ilâ sabîi rabbika bialhikmati wâlmaw'izhati alhasanati wajâdilhum biallatî hiya ahsanu inna rabbaka huwa a'lamu biman dhalla 'an sabîlihi wahuwa a'lamu bialmuhtadîna"

125. "Serulah (manusia) kepada jalan Tuhan-mu dengan hikmahdan pelajaran yang baik dan bantahlah mereka dengan cara yang baik. Sesungguhnya Tuhanmu Dialah yang lebih mengetahui tentang siapa yang tersesat dari jalan-Nya dan 
Dialah yang lebih mengetahui orangorang yang mendapat petunjuk." (QS: An Nahl:125)

Dari hasil penelitian diketahui meskipun konflik telah dikelola dengan strategi penanganan secara umum, tetapi penerapan pendekatan dalam rangka menjaga hubungan antar pelaku organisasi belum dilaksanakan secara maksimal. Forum-forum yang merupakan tempat bertukar informasi secara langsung dari atasan ke bawahan dan ke para stakeholder belum secara rutin dilaksanakan. Hal tersebut memicu adanya kecenderungan distrust dan kecenderungan rasa kurang diapresiasi dari kalangan bawah.

Penerapan strategi penanganan kompromis pada pengelolaan konflik di Pasar Induk Puspa Agro akan lebih maksimal jika diikuti dengan kemampuan mengelola hubungan antar individu melalui pola komunikasi yang baik seperti anjuran dalam Al Quran dalam menjalankan interaksi antar sesama:

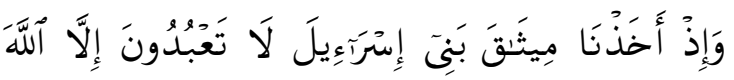

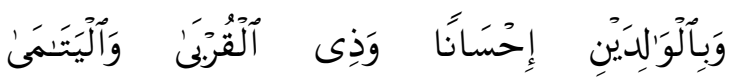

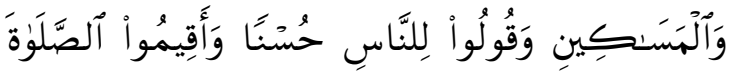

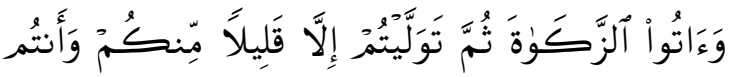

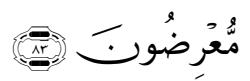

"Wa-idz akhadznâ mîtsâqa banî isrâ-îla lâ ta'budûna illâ allâha wabialwâlidayni ihsânan

wadzî alqurbâ wâlyatâmâwâlmasâkîni waqûlû lilnnâsi husnan waaqîmû alshshalâta wâatû alzzakâta tsumma tawallaytum illâ qalîlan minkum wa-antum mu'ridhûna"
83. Dan (ingatlah), ketika Kami mengambil janji dari Bani Israil (yaitu): janganlah kamu menyembah selain Allah, dan berbuat kebaikanlah kepada ibu bapa, kaum kerabat, anak-anak yatim, dan orangorang miskin, serta ucapkanlah kata-kata yang baik kepada manusia, dirikanlah shalat dan tunaikanlah zakat. kemudian kamu tidak memenuhi janji itu, kecuali sebahagian kecil daripada kamu, dan kamu selalu berpaling. (QS: Al Baqarah:83)

\section{KESIMPULAN DAN SARAN}

\section{A. Simpulan}

1. Konflik pada manajemen pasar Induk Puspa Agro bersumber dari internal dan eksternal perusahaan. Sumber konflik internal perusahaan terdiri dari ketidakjelasan wewenang,fungsi dan peran, lemahnya fungsi pengawasan dan evaluasi, lambannya pemimpin dalam merespon masalah, perbedaan kompetensi individu, target/beban kerja dan saling ketergantungan ltask interdependence). Sumber konflik eksternal terdiri dari kebijakan pemerintah dan untutan dunia industri.

2. Pengelolaan konflik yang dilakukan cukup mampu merepresentasikan teknikteknik pengelolaan konflik melalui metode stimulasi, pengurangan konflik dan resolusi konflik. Masing-masing metode diterapkan untuk konflik dengan kondisi tertentu, yaitu rendah, optimal dan tinggi. Kondisi konflik yang rendah dikelola dengan menggunakan metode stimulasi, konflik pada kondisi optimal dikelola dengan penerapan metode pengurangan konflik dan kondisi tinggi dikelola dengan penerapan resolusi konflik. Keseluruhan penerapan metode terepresentasikan dalam model metode pengelolaan konflik 
integratif. Pengelolaan konflik yang diterapkan telah sesuai dengan teknikteknik pengelolaan konflik dalam perspektif Islam. Teknik Ishlah diaplikasikan melalui metode resolusi konflik sedangkan at tabayyun direpresentasikan melalui metode pengurangan konflik.

3. Metode stimulasi konflik diwujudkan melalui penawaran reward and punishment dan perlakuan yang berbeda dari kebiasaan. Metode Pengurangan konflik diwujudkan melalui mengadakan forum dialog antar pihak yang berkonflik, mengadakan kegiatan bersamadan membuat tantangan baru. Metode resolusi konflik diwujudkan melalui ekspansi sumber daya, berkompromi, mengubah variabel struktur perusahaan, menghindar dan perintah otoratif.

\section{DAFTAR PUSTAKA}

Aamodt,

$$
\text { M.G. }
$$

2007. Industrial/Organizational

Psychology, An Applied Approach. 5th Edition. United States: Thomson Wordsmoth.

Afifuddin, Beni dan Ahmad Saebani. 2009. Metodologi Penelitian Kualitatif. Bandung: Pustaka Jaya.

Al Tabari,lbnu Jasin. 1997. Jami' Al-Bayan fi Ta'wil Al Qur'an. Vol.9. Saudi: Al Maktabah Al Shamilah.

Anoraga, Pandji dan Sri Suyuti. 1997. Perilaku Keorganisasian. Jakarta: PT. Dunia Pustaka Jaya.

Avruch. 1991. Introduction: Culture and Conflict Resolution. Dalam: Conflict Resolution: Cross-Cultural
Perspective. New York: Greenwood Press.

Daft, Richard L. 2011. Understanding Management. 8th Edition. Canada: Cangage Learning.

Depag RI. 1989. Al-Qur'an dan Terjemahnya. Surabaya: Surya Cipta Aksara.

Ebert dan Griffin. 2005. Business Essentials. New Jersey: Prentice Hall International.

Faisal, Sanapiah. 1982. Metodologi Penelitian Pendidikan. Surabaya: Usaha Nasional.

Gitosudarmo, Indriyo dan Sudita. 2008. Perilaku Keorganisasian. Edisi Pertama. Jogjakarta: Erlangga.

Hafidhuddin, Didin dan Tanjung. 2003. Manajemen Syariah dalam Praktek. Jakarta: Gema Insani Press.

Handoko, T. Hani. 1995. Manajemen. Ed.2. Yogyakarta: BPFE Yogyakarta.

Kusnadi. 2003. Masalah, Kerjasama, Konflik dan Kinerja. Malang: Tanada.

Lewicki,RJ dan J.A.Literer. 1985. Negotiation. Illinois: Homewood. Martoyo, Susilo. 1994. Manajemen Sumber Daya Manusia Edisi Ketiga. Yogyakarta: BPFE Yogyakarta. Marwansyah. 2010. Manajemen Sumber Daya Manusia (Edisi 2). Bandung: Alfabeta.

Moleong, M.A. Lexy J. 2011. Metode Penelitian Kualitatif. Bandung: Remaja Rosdakarya. 
Munawir, A.W. 1997. Kamus Al Munawir Arab-Indonesia Terlengkap. Surabaya: Pustaka Progresif.

Nimran, Umar. 1997. Perilaku Organisasi. Surabaya: Citra Media.

Qurtubi. 2004. Al Jami' Al Ahkam Al Qur'an. Vol.5. Saudi: Al Maktabah Al Shawilah.

Rivai, Veitzhal. 2005. Manajemen Sumber Daya Manusia Untuk Perusahaan. Jakarta: Raja Grafindo Perkasa.

Robbins, Stephen P. 2006. Organizational Behavior: Concepts, Controversies, Applications (7th Ed). New Jersey: Prentice Hall International.

1996. Organizational Behavior. New Jersey: Prentice Hall International.

1991. Organizational Behavior. New Jersey: Prentice Hall International.

Managing

Organizational Conflict: A Nontraditional Approach. New York: Prentice Hall.

Robbins, Stephen P., Judge. 2006. Organizational Behavior. 12th Edition. New York: prentice Hall.

Shiddieqy, Hasbi Ash., Muhammad. 2000. Tafsir Al Qur'anul Majid An Nuur. Cetakan kedua-Ed.2. Semarang: Pustaka Rizki.

Shihab, M.Quraish. 004. Tafsir Al Misbah. Cetakan kedua-Vol.13. Jakarta: Lentara Hati.
Siswanto, Bedjo. 1990. Manajemen Modern : Konsep dan Aplikasi. Bandung: Sinar Baru.

Slide profile PT. Jatim Grha Utama. 2013. Surabaya.

Stoner, James A.F., Freeman. 1989. Principle of Management. 4th Edition. England: Longman Higher Education.

Suriasumantri, JujunS. 2001. Filsafat Ilmu: Sebuah Pengantar Populer. Jakarta: Pustaka Sinar Harapan.

Surwandono dan Ahmadi. 2011. Resolusi Konflik di Dunia Islam. Yogyakarta: Graha IImu.

Wahyudi. 2008. Manajemen Konflik dalam Organisasi. Bandung: Alfabeta.

Wijono, Sutarto. 1994. Konflik dalam Organisasi/Industri dengan Strategi Pendekatan Psikologis. Semarang: Satyawaca.

Winardi. 1994. Manajemen Konflik (Konflik Perubahan dan Pengembangan). Bandung: CV. Mandar Maju.

Wirawan. 2009. Evaluasi Kinerja Sumber Daya Manusia. Jakarta: Erlangga.

Wood, Jack dkk. 1998. Organizational Behavior An Asia-Pasific Perspektve. Queesnland : Bracken Ridge.

Yin, Robert K. 2009. Studi Kasus (Desain dan Metode). Jakarta: PT. Raja Grafindo Persada. 